A N N A L E S

UNIVERSITATIS MARIAE CURIE-SKŁODOWSKA

LUBLIN - POLONIA

VOL. LXVI, 1

SECTIO G

2019

Uniwersytet Marii Curie-Skłodowskiej w Lublinie

LESZEK LESZCZYŃSKI

leszek.leszczynski@poczta.umcs.lublin.p1

ORCID: 0000-0003-4300-5461

\title{
O japońskim porządku prawnym - między literą prawa a otwartością norm
}

On the Japanese Legal Order - Between the Letter of Law and the Openness of the Norms

\section{WPROWADZENIE}

Japoński porządek prawny jest bez wątpienia elementem dalekowschodniej kultury prawnej. Obejmuje ona w miarę zwarty obszar Azji Południowo-Wschodniej, na którym - obok japońskiego - funkcjonują porządki prawne przede wszystkim Chin (ChRL i Tajwanu), Singapuru i Korei Południowej. Niezależnie od związku tych porządków z pewnymi cechami prawa Tajlandii, Kambodży, Wietnamu czy nawet Korei Północnej, należy zauważyć istotne odrębności, w ramach których porządek japoński traktowany jest jako najmocniej powiązany - zarówno formalnie, jak i treściowo - z zachodnią kulturą prawną.

„Wędrówkę” przez cechy japońskiego porządku prawnego rozpoczniemy od zasygnalizowania podstaw doktrynalnych oraz wskazania kilku zasadniczych cech kultury społecznej, na gruncie których można wyjaśnić wpływ norm społecznych i nieformalnych sposobów decydowania na kształt i treść norm i decyzji prawnych, a także w jakimś sensie zaskakującą „łatwość” w przejmowaniu (recypowaniu) obcych rozwiązań prawnych. Pozwoli to na podjęcie próby wyważenia proporcji między literą i formą prawa a otwartością jego norm.

\section{WPEYW DOKTRYNY FILOZOFICZNEJ}

Tło filozoficzne całej kultury dalekowschodniej wiąże się z wpływem koncepcji Konfucjusza (ur. 551 r. p.n.e.), która przezwyciężywszy na wskroś decen- 
tralistyczną i w pewnym sensie indywidualistyczną koncepcję Lao-cy, stała się rodzajem oficjalnej ideologii w państwach tego regionu. Jej główne idee określają miejsce człowieka (jest on częścią harmonijnie zintegrowanego porządku naturalnego), jego postawę w stosunku do otoczenia (powinien raczej cierpieć z powodu szkód, jakie powoduje, niż dochodzić swych praw), strukturę społeczną (porządek w rodzinie i państwie jest celem wszelkich działań, a harmonia społeczna jest skorelowana $\mathrm{z}$ hierarchią grupową, w ramach której władza i urzędnicy zajmują miejsca naczelne) oraz powstające i obowiązujące w niej reguły (podstawową rolę odgrywają uświęcone tradycją obyczaje) ${ }^{1}$. Na gruncie wpływu konfucjanizmu na porządek społeczny wykształciły się w tych społeczeństwach więzi, które - mówiąc najogólniej - opierają relacje jednostki ze społeczeństwem na kolektywizmie oraz harmonii i hierarchii².

O ile w Chinach doktryna konfucjańska bywała w pewnym zakresie, mniej lub bardziej skutecznie modyfikowana, o tyle w Japonii nie było myśliciela w rodzaju Mo-ti, kwestionującego myśl konfucjańskąa ${ }^{3}$ Idea zasadnicza podlegała tu raczej pogłębiającemu się ugruntowaniu, czemu dodatkowo sprzyjał ewolucyjny rys historii kraju. Aż do epoki Edo (początek XVII w.), poszczególne epoki (Jomon, Yayoi, Yamato, Asuka, Nara, Heian, Kamakura, Muromachi, Momoyama) nie charakteryzowały się bowiem wydarzeniami, które mogłyby istotnie zakłócić ten harmonijny przebieg. Bez wątpienia zarówno ta „moc własnej tradycji”, jak i pokrewieństwo cech kulturowych stanowiły podstawy dla powszechnie akceptowanych i skutecznych recepcji do Japonii różnych rozwiązań społecznych, w tym również rozwiązań prawnych z Chin. Miało to miejsce właściwie w całym tym okresie, a jego najbardziej trwałym elementem formalnym było przyjęcie chiń-

1 Por. G.L. Seidler, Przedmarksowska myśl polityczna, Kraków 1974, s. 30-38, zwłaszcza s. 34-38; L. Dubel, J. Malarczyk, Historia doktryn polityczno-prawnych, Lublin 1997, s. 16-19. O szczegółowych analizach wpływu myśli konfucjańskiej na porządek społeczny i prawny w Chinach por. A. Kość, Prawo a etyka konfucjańska w historii myśli prawnej Chin, Lublin 1998, zwłaszcza s. 65 i n.; M. Stępień, Spór konfucjanistów z legistami. W kręgu chińskiej kultury prawnej, Kraków 2013, zwłaszcza s. 49 i n.

2 Nawiązanie do idei hierarchii i harmonii w odniesieniu do systemu władzy widoczne jest w następujących słowach Konfucjusza: „Kto cnotą [te] rządy sprawuje, jest jako gwiazda polarna, co sama w miejscu pozostaje, a wszystkie gwiazdy wokół niej krążą” oraz „Niechaj władca, ludowi się ukazując, zachowa poważną postawę, a lud będzie żywił dlań szacunek. Niechaj się z nabożnością (hiao) odnosi do swych rodziców i dla ludu będzie łagodny, a wówczas lud będzie mu wierny. Niechaj na urzędy wynosi dobrych i naucza tych, którzy jeszcze nie osiągnęli cnoty, a wówczas sprawi on, że lud się będzie ku cnotom skłaniał” czy też „Aby władać państwem, trzeba znać obyczaje (li)” lub „Władca powinien tak ludowi przewodzić, by ów, pracując w pocie czoła, nie odczuwał trudu" - Dialogi konfucjańskie, Wrocław 1976, cyt. za: Historia doktryn politycznych i prawnych do początku XX wieku. Materiały źródłowe, oprac. L. Dubel, Lublin 2003, s. $21,22,24,25$.

3 Por. G.L. Seidler, op. cit., s. 38 i n. 
skiego systemu ideogramów Kanji, który stał się głównym, chociaż nie jedynym ${ }^{4}$, składnikiem języka japońskiego.

\section{KULTUROWE CECHY SPOŁECZNE}

Jak wspomniano wyżej, dalekowschodni, a więc także japoński, porządek społeczny polega na współwystępowaniu trzech zasadniczych cech kształtujących relacje społeczne i mających istotny wpływ na funkcjonowanie porządku prawnego ${ }^{5}$. Pierwszą z nich jest naturalnie odczuwany i praktykowany swoisty kolektywizm, polegający na potrzebie przynależności do grupy i identyfikacji $\mathrm{z}$ nią. Efektem tej postawy jest, mówiąc najogólniej, nieindywidualistyczny sposób funkcjonowania w społeczeństwie, $\mathrm{z}$ czym wiąże się słabsza pozycja konstrukcji normatywnych i systemów ochrony praw człowieka (przynajmniej w ich zachodnim rozumieniu i zakresie ochrony).

Prowadzi to do ostrego określenia granicy „własnej grupy” (niezależnie od jej rodzaju) oraz jej sfery wewnętrznej ( $u c h i$, co oznacza także „dom”), w stosunku do której kształtują się zasadnicze więzi, nieprzejawiane w taki sposób w odniesieniu do „obcych” (soto). Wykluczenie z grupy jawi się w takim układzie jako marginalizacja społeczna. Co ważne, takimi podstawowymi grupami identyfikacyjnymi dla postrzegania powyższych właściwości są przede wszystkim rodzina i grupa zawodowa (w skomplikowanej i niejednoznacznej relacji pierwszeństwa ważności), następnie zaś grupa sąsiedzka, towarzyska czy religijna jako dodatkowe punkty odniesienia oraz grupa ujawniana raczej w wyjątkowych okolicznościach, obejmująca społeczeństwo (naród).

Postrzeganie przynależności do grupy jako ważnej motywacji działania społecznego generuje dwie następne cechy kulturowe, mające już bezpośredni związek z funkcjonowaniem prawa. Pierwszą z nich jest hierarchia w ramach grupy, natomiast drugą - obowiązek dążenia do jej harmonijnego funkcjonowania.

Hierarchia $\mathrm{w}$ grupie oznacza obowiązek przestrzegania poleceń płynących „z góry”, od tych członków grupy, którzy znajdują się wyżej w hierarchii, ze szczególnym uwzględnieniem pozycji tych, którzy są na czele struktury grupowej. Może to być głowa rodziny, utożsamiana z ojcem (czy najstarszym męskim człon-

4 Reguła, że każda recepcja w Japonii nie wypełnia całości zjawiska i pozwala na łączenie jej efektu z własnymi rozwiązaniami, znajduje w tym aspekcie zastosowanie w postaci faktu, że japoński język pisany - obok zbioru recypowanych ideogramów Kanji - obejmuje ponadto już rodzime „alfabety”: hiragana i katagana, a także (coraz częściej stosowany) recypowany alfabet łaciński (romaji).

5 Por. C. Nakane, Nihonteki Shakai-Kozo no Hakken, Tokio 1967, passim; eadem, Tatashakai no Ningenkankei - Tanitsushakai no Riron, Tokio 1967, passim; T. Doi, The Anatomy of Self: The Individual versus Society, Tokio-New York 1988, s. 78 i n. Por. także: L. Leszczyński, Japonia kontynuacje i negacje, Lublin 1994, s. 33-62. 
kiem rodziny) w tradycyjnym (ciągle jednak oddziałującym na życie społeczne) systemie Iye. Może to być szef firmy (lub jej mniejszej jednostki organizacyjnej), ale także piastun władzy publicznej, lokalnej lub centralnej, prawodawczej, wykonawczej lub sądowniczej, co ma już decydujące znaczenie dla skuteczności prawa i jego egzekwowania.

Sprawność systemu więzi społecznych jest dodatkowo wzmacniana przez cechę trzecią, oznaczającą odczuwanie obowiązku przyczyniania się do stanu harmonii we „własnej grupie”. Konsens grupowy polega głównie na dążeniu do niepowstawania konfliktów. Jeśli już one jednak powstaną, niezależnie od obowiązku ich nieujawniania na zewnątrz, poszukuje się ,łagodnego” sposobu rozwiązania problemu. Sprzyja temu wskazana wcześniej hierarchia wyznaczająca w sposób naturalny arbitra. Ma to niebagatelne znaczenie dla powstawania i rangi różnorodnych form mediacji społecznych, stanowiących przykład alternatywnego w stosunku do klasycznych instrumentów sądowych sposobu rozwiązywania problemów, także prawnych (w ramach których w wielu przypadkach istnieje już od początku okresu Edo obowiązek podjęcia ,próby mediacyjnej”).

Powyżej dostrzeżone cechy kulturowo-społeczne, powiązane z ideą giri (uświadomiony obowiązek społeczny) oraz ninjo (ludzkie uczucia), prowadzą jak się wydaje - do ukształtowania się dominującej postawy prawnej łączącej prawa i obowiązki oraz promującej swoiście rozumiany legalizm (w odniesieniu do szanowania norm ukształtowanych w hierarchicznej, mniej lub bardziej sformalizowanej strukturze grupowej) i konformizm (w odniesieniu do mocnej łączności z innymi członkami harmonijnie funkcjonującej grupy). Przekłada się to na szereg właściwości porządku prawnego w kontekście zbioru źródeł prawa oraz procesów jego stosowania i społecznego działania.

\section{PODSTAWOWE WŁAŚCIWOŚCI PORZĄDKU PRAWNEGO}

\section{System źródel prawa a rola kryteriów pozasystemowych}

Prawo japońskie jest przykładem porządku prawa stanowionego, w którym funkcję formalnych źródeł prawa pełnią akty normatywne. Na czele ich systemu stoi konstytucja (kempo), a główną rolę odgrywają ustawy (horitsu) i powszechnie obowiązujące akty wykonawcze, występujące w postaci rozporządzeń (serei), pozostawiające pewną sferę autonomii aktom prawa lokalnego ustanawianym przez ciała samorządowe (yorei). Nie zmienia tych właściwości obecność aktów kierownictwa wewnętrznego (kisoku, tsutatsu), wiążąca się przede wszystkim ze zwiększoną w stosunku do systemów liberalnych ingerencją państwa w szeroko rozumiane procesy gospodarcze. Wprawdzie niektóre z form takich aktów (yokoshido, kankoku) są na tyle charakterystyczne dla tego porządku prawnego, że przypisuje się im cechy prawotwórstwa nieformalnego, niemniej stanowią one, 
łącznie z innymi „źródłami nieformalnymi”, efekt znacznie szerszej konwencji „otwierania" systemu'.

Jeden z najbardziej zasadniczych rysów japońskiego porządku prawnego wiąże się z decydującą rolą autonomicznych norm społecznych, kształtowanych w mocno związanej wewnętrznie grupie (normy moralne oraz zwyczajowe) i funkcjonujących obok formalnego systemu norm prawnych ${ }^{7}$.

Rola autonomicznych reguł społecznych wiąże się z ich szanowaniem w codziennych zachowaniach społecznych, powodujących ich moc, która często przekracza skalę podległości formalnej literze prawa egzekwowanej przez sądy. Stąd wynika niekiedy mocniejsza orientacja na autonomiczną reakcję grupy niż na sankcję wyznaczoną przez sąd. Poza odgrywaniem samodzielnej roli oddziałują one bezpośrednio na procesy tworzenia i stosowania prawa poprzez włączanie się w oba rodzaje procesów decyzyjnych, w efekcie czego sama treść norm oraz treść podejmowanych na ich podstawie decyzji prawnych uwzględnia bezpośrednio te autonomiczne reguły i wartości.

Dwa rodzaje tych kryteriów pozasystemowych odgrywają rolę szczególną. Pierwszym są normy zwyczajowe (kanshun), kształtujące pierwotne oraz niezależne od norm prawnych wzory zachowań. Drugi rodzaj wartości i norm występuje pod zbiorczą nazwą jori, której znaczenie należałoby wiązać z odwołaniem się do kryteriów społecznego rozumienia sprawiedliwości, naturalnego rozumu, prawa naturalnego, ogólnych zasad prawa czy też pożądanego stanu rzeczy ${ }^{8}$. Kategoria ta nieco przypomina znaną $\mathrm{w}$ kontynentalnych europejskich porządkach prawnych konstrukcję generalnych klauzul odsyłających (np. w art. 7 austriackiego ABGB upoważaniających sędziego do wykorzystania podobnie brzmiącego kryterium: naturalnych zasad prawa - natürliche Rechtsgrundsätze), niemniej - jak się wydaje - ta rola jest szersza, stanowi ona w istocie nawiązanie do upoważnienia nie punktowego, lecz generalnego. Oto bowiem w art. 3 dekretu z 1875 r. o stosowaniu prawa jori ma stanowić podstawę dla podejmowania decyzji sądowych wówczas, gdy brak jest wyraźnych reguł prawa pisanego oraz prawa zwyczajowego (kanshunho). Normy te mogą zatem wpływać na wykładnię sformalizowanych norm prawnych, ale mogą też wchodzić z nimi w kolizję, aż po działanie jako samodzielna podstawa decydowania, jeśli prawo formalne czy nawet prawo zwyczajowe nie stanowi „wyraźnych regul”. Trudno o mocniejsze podkreślenie roli autonomicznych norm społecznych. W tym kontekście przypomina to nieco regulację późniejszego (1907) szwajcarskiego Zivil Gezetzbuch, niżej).

6 W pewnym sensie stając się podstawą konkretnych zaleceń w postaci gyoseishido (por.

Por. J.O. Haley, The Role of Law in Japan: An Historical Perspective, "Kobe University Law Review" 1984, No. 18, s. 18 i n.; M.K. Young, The Japanese Legal System, History and Structure, [w:] Doing Business in Japan, ed. Z. Kitagawa, Vol. 2, New York 1986, s. 47 i n.

8 Por. ibidem, s. 28. 
który w art. 1 wskazuje na zwyczaje jako źródło prawa, w art. 2 odsyła do kryteriów dobrej wiary, natomiast w art. 4 upoważnia sędziego do orzekania na podstawie zasad słuszności (Billigkeit).

Tendencja ta wydaje się zresztą uniwersalna w całej kulturze dalekowschodniej. Współdziałanie kodeksów pisanych oraz kryteriów otwartych widoczne jest bowiem również w Chinach, gdzie już od czasu panowania dynastii Tang (około VII w.) dostrzegano pozycję reguł li (ogólnie mówiąc, zasad dobrego wychowania), które odgrywały decydującą rolę zwłaszcza w dziedzinie prawa prywatnego, a także w Korei, gdzie podobną funkcję pełnią reguły $y e^{10}$.

\section{Zalecenia administracyjne (gyoseishido) i ich sądowa kontrola}

Znaczenie reguł pozaprawnych, ale już tych, które mają bardziej polityczną niż społeczną proweniencję, przejawia się też w tym, iż funkcjonują $\mathrm{w}$ japońskim porządku prawnym nieformalne zalecenia (gyoseishido ${ }^{11}$ ), znajdujące swą podstawę $\mathrm{w}$ cesze hierarchii $\mathrm{w}$ grupie ( $\mathrm{w}$ tym przypadku $\mathrm{w}$ pozycji biurokracji W społeczeństwie zorganizowanym w państwo). Zalecenia te pochodzą od organów administracji publicznej (centralnej i lokalnej) i dotyczą całej gamy różnych spraw: od edukacyjnych, przez procesy budowlane czy inwestycyjne, aż po działania stricte gospodarcze, w tym handlowe. Nie wiążą one adresatów (często są nimi wiodące firmy, nie tylko w skali krajowej) formalnie. Wspomniana wyżej cecha dążenia do konsensu oraz posłuszeństwo wobec administracji reprezentującej władzę powodują jednak, że faktycznie zalecenia te są przestrzegane. Dzieje się tak nawet wówczas, jeśli nakłaniają one do działań niezgodnych z formalnie obowiązującym prawem pisanym. Najbardziej wyraźny (chociaż nie pierwszy) przykład skuteczności gyoseishido można zaobserwować w przypadku tzw. kartelu naftowego z lat 70. XX w., niweczącego normy ustawy antymonopolowej (Shitei Dokusen no Kinshi oyobi Kosei Torihiki no Konkuho ni Kansuru Horitsu) z 1947 r. ${ }^{12}$ Otóż Ministerstwo Handlu Międzynarodowego i Przemysłu zalecało w czasie tzw. kryzysu naftowego firmom naftowym przyjmowanie uzgodnionych między sobą cen i wielkości ropy naftowej sprowadzanej do Japonii, co właśnie spowodowało powstanie nieformalnego kartelu, uzasadnianego przez Ministerstwo ochroną społeczeństwa przed wysokimi cenami paliw. Reguły państwa

9 Por. P. Tuor, Das Schweizerische Zivilgesetzbuch, Zurich 1934, s. 38-47.

10 Por. C. Choi, Ancient and New Sources of Law: An East-Asian Perspective, [w:] Challenge to Law at the End of the $20^{\text {th }}$ Century, ed. E. Pattaro, Vol. 2, Bologna 1995, s. 80-89.

11 Por. S. Hayashi, Iwayuru Gyosei Shido ni Tsuite, "Gyosei to Keiei” 1962, No. 4, passim; H. Shiono, Gyosei Shido, "Gyoseiho Koza” 1965, No. 6, passim; Y. Narita, Administrative Guidance, "Law in Japan. An Annual" 1968, No. 2, passim; T. Fujita, Gyoseishido. Rechtsprobleme eines Hauptmittels der gegenwartigen Verwaltung in Japan, "Die Verwaltung“" 1982, Nr. 2, passim.

12 Ustawa nr 54 z 1947 r. 
prawnego doprowadziły wprawdzie do procesów sądowych wszczętych przez Komisję Uczciwego Handlu (Kosei Torihiki Iinsai) wobec recypientów tych „,zaleceń”, gorliwie zresztą przestrzeganych, niemniej zakończyły się one zupełnie symbolicznymi wyrokami skazującymi adresatów zaleceń (jako niewiążące nie mogły wszak obciążać urzędników Ministerstwa). Sądowa kontrola legalności działania zarówno firm, jak i administracji ministerialnej napotkała zatem istotną przeszkodę w postaci funkcjonowania instytucji, która wykorzystując dążenie do niesprzeciwiania się biurokracji ministerialnej, niezależne od braku formalnego obowiązywania dyrektywy „wykorzystała” łącznie cechę harmonii społecznej i konsensu oraz postrzegania roli hierarchii w strukturze organizacyjnej państwa, praktycznie eliminując możliwość skonfrontowania działań bezprawnych z wzorami zachowania formalnie wyrażonymi w ustawie antymonopolowej, traktowanej w jakimś wymiarze jako akt (w pewnym sensie narzucony w trakcie „okupacji” amerykańskiej) ustanawiający standardy działań gospodarczych niemieszczących się w tradycji japońskiej ${ }^{13}$.

Składnikiem tej ostatniej, mówiąc najogólniej, jest ścisła współpraca firm (zwłaszcza największych i najważniejszych, niejednokrotnie wyrosłych z powstałych po wojnie zaibatsu) oraz stowarzyszeń gospodarczych (jak np. Federacja Organizacji Gospodarczych Keidanren) z administracją państwową. Każda ingerencja „modelu liberalnego" w jakimś zakresie osłabia tę praktykę, obecną także w Korei Południowej (tu analogiczną rolę odgrywają tzw. czebole), Singapurze, na Tajwanie oraz w Chinach. W tym ostatnim państwie wpływ na procesy gospodarcze oraz same zalecenia mogą dodatkowo przybierać postać dyrektyw stricte politycznych, co jest związane z komunistycznym systemem ideologicznym (zmodyfikowanym w Chinach w sferze zjawisk gospodarczych przez przyjęcie ograniczonych mechanizmów rynkowych), w wielu miejscach skutecznie wspieranym przez tradycyjne cechy kulturowe społeczeństw Azji Dalekowschodniej.

\section{Mediacje a orzekanie sądowe}

Jednym z najistotniejszych rysów „proceduralnych” japońskiego porządku prawnego jest rola mediacji jako sposobu rozwiązywania sporów ${ }^{14}$, wspierana przez oddziaływanie autonomicznych reguł grupowych na treść prawa, a także przez kulturowo ugruntowaną cechę dążenia do niegenerowania konfliktów w grupie, a jeśli już one powstaną, to do ich nieujawniania na zewnątrz grupy, a już na pewno do nieoddawania ich osobom trzecim do rozstrzygnięcia.

13 Por. L. Leszczyński, Gyoseishido w japońskiej kulturze prawnej. Nieformalne działania administracji a prawo, Lublin 1996, s. 81 i n. oraz przywołana tam literatura.

14 Por. T. Kawashima, The Legal Consciousness of Contract in Japan, "Law in Japan. An Annual" 1974, No. 7. 
Tak wyrazisty kontekst kulturowoprawny mediacji wynika z historii społecznej tego kraju, w ramach której ( $\mathrm{w}$ tym w związku z trudnymi warunkami geograficzno-przyrodniczymi archipelagu) cementowanie więzi grupowych w celu przezwyciężania powodowanych przez te warunki trudności musiało wiązać się z harmonią i łagodnymi formami zażegnywania i rozwiązywania sporów. W okresie Edo (1603-1868), mającym już bardziej bezpośredni związek ze współczesną Japonią, mediacja stała się nie tylko powszechnym zjawiskiem społecznym, ale też składnikiem prawa, ponieważ wprowadzono m.in. obowiązek ,próby mediacyjnej” w odniesieniu do każdego sporu prawnego. Ta swoista „mediacja przymusowa", przekształcona później w dobrowolną, prowadzona przez osobę pochodzącą z danej grupy (senior), stała się kanonem i już tego statusu nie utraciła mimo pewnych niekoniecznie sprzyjających temu rozwiązań prawnych recypowanych z Niemiec w okresie Meiji (1869-1912).

Można, jak się wydaje, zaryzykować tezę, iż okres bezpośrednio powojenny, określany jako „okupacja amerykańska”, przyniósł wprawdzie liberalizację prawa w wyraźnym wymiarze niezgodną z tradycją japońskiego „kolektywizmu”, ale zarazem niejako à rebours wzmocnił mediację $\mathrm{w}$ tym kraju z racji szerokiego procesu równoległego rozwoju tej formy prawnej w USA (w postaci Alternative Dispute Resolution) i traktowania jej tam jako rodzaj partycypacyjnego, demokratycznego i życzliwego adresatowi sposobu rozwiązywania konfliktów.

W efekcie tego i dziś można wskazać na doniosły udział mediacji nie tylko jako odrębnej formy, lecz także jako składnika procesu sądowego stosowania prawa. W ramach szeroko rozumianej procedury sądowej (uruchamianej już po wpłynięciu sprawy do sądu) można wyróżnić wstępną, niejako „przedproceduralną", ale obowiązkową fazę mediacyjną, która poprzedza sformalizowaną mediację odbywaną przez sędziego. W wyniku tych złożonych strukturalnie działań proporcje między „wymediowaniem” rozwiązania w fazie wstępnej, zakończeniem sprawy w mediacji sądowej oraz rozstrzygnięciem sprawy przez sędziego rozkładają się po około jednej trzeciej, co oznacza, że jedynie około 30\% spraw wniesionych kończy się klasycznym rozsądzeniem sporu. A przecież jest jeszcze „ciemna liczba” spraw, które zostały zakończone „nie-sądową” mediacją w grupie odniesienia zanim sprawa została wniesiona do sądu. Jej skuteczność wiąże się z przekonaniem, że każde powierzenie sporu sądowi oznacza - kłócące się z istotą idei harmonii grupowej - oddanie sprawy do rozstrzygnięcia osobie trzeciej.

\section{Recepcje litery prawa a jego społeczne dzialanie}

Cechą rozwoju japońskiego porządku prawnego, wiążącą się z właściwościami wskazanymi powyżej, jest recypowanie rozwiązań prawnych z innych systemów państwowych. Co charakterystyczne, nie jest to cecha wyłącznie porządku japońskiego, ponieważ w drugiej połowie XIX w. na skutek zawarcia traktatów 
międzynarodowych także w Chinach nastąpiło „otwarcie” na rozwiązania funkcjonujące $\mathrm{w}$ państwach zachodnich, unowocześniające co do zasady feudalną jeszcze strukturę państwową i prawną obu państw azjatyckich. O ile w Chinach recepcja ta nie została przeprowadzona całościowo z powodu załamania się systemu cesarskiego (1912) i następnie dominacji odrzucającej wpływy zachodniej ideologii komunistycznej, prowadzącej do powstania Chińskiej Republiki Ludowej, o tyle w Japonii recepcja ta wpłynęła głęboko na zmiany w prawie.

Wpływ tej właśnie recepcji, zwanej recepcją Meiji, miał wprawdzie miejsce po ponad 250-letnim okresie programowej i niemal kompletnej izolacji Japonii w okresie Edo, niemniej został on poprzedzony recepcją już raz w tym państwie dokonaną. Taka bowiem była recepcja chińskich kodeksów prawa karnego z epok Ming i Ching. Niezależnie od faktu, że jej kierunek obejmował ten sam krąg kultury politycznej i prawnej, jej sukces stanowił zaczątek postawy, która pozwoliła na przejmowanie pod pewnymi warunkami starannie wybranych rozwiązań, o ile mogły się one okazać użytecznymi.

Postawa ta ujawniła się w okresie recepcji Meiji, która nie tylko otworzyła kraj międzynarodowo, ale też doprowadziła do modernizacji struktur społecznych, politycznych oraz systemu prawnego ${ }^{15}$. Początkowa debata nad przyjęciem rozwiązań angielskich, francuskich i niemieckich doprowadziła do ustalenia kierunku recepcji na niemiecki, co do zasady najbardziej z tych trzech zbliżony (mimo szeregu odrębności) do tradycyjnych japońskich cech kulturowo-społecznych. Reforma zapoczątkowana wydaniem Konstytucji (1889) opartej na pruskiej Karcie konstytucyjnej z 1850 r. oraz kodeksu cywilnego (1898) opartego na niemieckim BGB z 1896 r. objęła również kodyfikację karną i handlową oraz kodyfikacje proceduralne. Już wówczas wskazywano, że recepcja litery prawa nie oznacza bezkrytycznego przyjęcia sposobu stosowania i społecznego działania prawa, w ramach których - także na skutek przyjęcia wspomnianego wcześniej dekretu o stosowaniu prawa z 1875 r. - porządek prawny należy widzieć w świetle tradycyjnych i autonomicznych norm społecznych.

Sukces tej recepcji, jednocześnie modernizującej i „chroniącej” tradycyjne rozwiązania (np. system hierarchicznej rodziny Iye oraz małżeństw omyai), ujawnił przekonanie już formalnie „otwartego” od czasów epoki Meiji społeczeństwa co do możliwości przejmowania obcych, z jakichś powodów użytecznych rozwiązań. Dlatego gdy przyszło zaakceptować narzucone rozwiązania amerykańskie po II wojnie światowej, które liberalizowały efekty poprzedniej recepcji „,niemiec-

15 Por. K. Mukai, N. Toshitani, Meiji Zenki ni okeru Mimpo-ten hensen no Keika to mondaiten, "Hosei Shi Kenkyu Bessatsu" 1964, No. 14, s. 25 i n.; Z. Kitagawa, Theory Reception - One Aspect of the Development of Japanese Civil Law Science, "Law in Japan. An Annual" 1970, No. 4, s. 1-18; J. Tanaka, Shihoken no Genkai, Tokio 1976, passim. 
kiej”, Japończycy to uczynili ${ }^{16}$. Nawet jeśli protesty były widoczne (np. co do przyjęcia Konstytucji z 1946 r., a zwłaszcza do jej utrzymania po zakończeniu okresu okupacji amerykańskiej w 1952 r.), to oczekiwania na kolejną modernizację przeważyły nad wątpliwościami. Stworzono na jej podstawie zarówno nowe regulacje (rodzinną, karną, procedury karnej), jak i nowe instytucje prawne (takie jak sądowa kontrola konstytucyjności ustaw czy działań administracji) oraz nowe ustawy (jak np. wspomniana już ustawa antymonopolowa z 1947 r.), wzorowane na rozwiązaniach amerykańskich, które w porównaniu z rozwiązaniami niemieckimi z okresu Meiji jeszcze wyraźniej odbiegały od tradycyjnych cech społecznych w Japonii, ale które dzięki liberalizacji pozwoliły na niespotykany rozwój gospodarczy Japonii, począwszy od lat 60 . XX w.

Ta trzecia już recepcja, tworząc $\mathrm{w}$ istocie wielowarstwową strukturę prawną, umocniła uwidocznioną $\mathrm{w}$ trakcie poprzedniej recepcji postawę, którą można określić jako „pragmatyczną łatwość” przejmowania obcych wzorów, ograniczającą się jednak do „przeszczepiania” na własny grunt formy (litery prawa) przy pozostawieniu istotnej roli rozwiązaniom tradycyjnym, mocno zakorzenionym w społeczeństwie. Pozwala to na nawiązanie do zaznaczonej w tytule opracowania relacji między sformalizowaną literą prawa a otwartością jego porządku normatywnego.

\section{PRAWO JAPOŃSKIE MIĘDZY TATEMAE A HONNE (?)}

Grupowość i zamknięcie harmonijnie funkcjonującej i hierarchicznie zorganizowanej grupy znajdują swój wyraz na gruncie odzwierciedlającego te cechy języka. Jednym z najważniejszych przejawów tego zjawiska jest odróżnienie pojęć tatemae i honne, a także w pewnym sensie pojęć powiązanych: omote i ura. Termin tatemae, oznaczający pogląd prezentowany na zewnątrz, umożliwia powiązanie go z odwołaniem się do ,powierzchniowej”, a tym samym „nieukrywalnej” strony każdego zjawiska (tak jak niemożliwa do ukrycia jest zewnętrzna część dłoni nazywana omote). Można się podzielić jej treścią z każdym (w tym z obcym) chociażby po to, aby uzasadnić swoją pozorowaną otwartość czy oczekiwaną przez otoczenie nowoczesność. Pozostawić natomiast tylko sobie i członkom swojej grupy można głęboką i ,prawdziwą” (honne) stronę takiej możliwej do „ukrycia” treści (tak jak można ukryć wewnętrzną i zamkniętą część dłoni, zwaną ura).

${ }^{16}$ K. Takayanagi, Contact of the Common Law with the Civil Law in Japan, "Japan Annual of Law and Politics" 1955, No. 3, s. 4 i n.; idem, The Conceptual Background of the Constitutional Revision Debate in the Constitution Investigation Commission, "The American Journal of Comparative Law" 1967, Vol. 4(1), DOI: https://doi.org/10.2307/837044, s. 2-22; I. Hata, Japan under Occupation, "Japan Interpreter" 1976, No. 3-4, s. 361-377. 
Można to przenieść na rozumienie prawa i jego społecznej roli. Sfera tatemae (omote) będzie się wówczas wiązać z "literą prawa”, jego formą, systemem regulacji (przepisów) zgrupowanych w publikowane (a więc „widoczne" na zewnątrz własnej grupy) akty prawne (formalne źródła prawa), które - dzięki recepcjom (w zasadzie nieważne, czy dobrowolnym czy przyjętym pod wpływem siły politycznej) z innych (nawet wyraźnie oddalonych kulturowo) porządków prawnych - może uchodzić za porządek nowoczesny, a tym samym akceptowany przez np. społeczność międzynarodową. Z kolei sfera honne (ura) będzie się wiązać z otwieraniem się na tradycyjne i własne regulatory życia społecznego, ukształtowane autonomicznie w toku ewolucji, które istniejąc w głębszej strukturze społecznej, mogą stać się (i często się stają) niewidoczne dla obcych (a przynajmniej dają się przed nimi ukryć) i pozostać „naszymi” wzorami i wartościami. To one przede wszystkim, właśnie jako „nasze”, są rzeczywistymi regulatorami życia „naszych” społeczności.

Odniesienie grupy do całego społeczeństwa zorganizowanego w państwo pozwoliło na łatwe uzyskanie akceptacji recepcji prawa obcego do Japonii (najpierw z Chin, potem z Niemiec i USA), mimo że nominalnie poszczególne recepcje oznaczały niezgodne $\mathrm{z}$ istotą grupowości otwarcie się na zewnątrz, nie niwelowały też wpływu tradycyjnych norm społecznych, które albo ograniczały zakres faktycznego obowiązywania przejętych rozwiązań, albo skutecznie wpływały na uzasadniony tradycją sposób ich stosowania. Stąd tak trudno było poddać kontroli prawnej (sądowej) akty zalecania administracyjnego (gyoseishido), ponieważ niezgodność z normami ustawy antymonopolowej okazała się mniej ważna niż tradycyjne powiązania pomiędzy przedsiębiorstwami zawiązującymi kartel a biurokracją realizującą interes ogólnospołeczny. Biorąc to pod uwagę, można wyjaśnić mniejszą (w porównaniu z innymi rozwiniętymi społeczeństwami) liczbę oraz rolę prawników i sądów w procesach społecznego działania prawa. Otóż konflikt czy spór, którego już się nie dało uniknąć, mógł być rozwiązany w drodze mediacji opartej na harmonii i hierarchii grupowej. Stąd wreszcie w samym pojęciu prawa, lokującego się w ramach porządków prawa stanowionego, obok formalnych aktów normatywnych znajdujemy zwyczaje i jori, skutecznie nie tylko „zmiękczające” oficjalny porządek normatywny, lecz także wprowadzające doń ów autonomiczny substrat społecznych tradycji, rozumienia sprawiedliwości i reguł słuszności.

Japoński porządek prawny ewoluuje jak każdy inny, a tradycyjne regulatory współgrają z regulatorami formalnymi, prowadząc do relacji bardziej złożonych niż te, które wynikałyby z zasygnalizowanego wyżej tradycyjnego modelu. Zwłaszcza kilka ostatnich dekad należy rozpatrywać w perspektywie wyraźnych zmian, lokujących ten porządek jeszcze bliżej zachodniej kultury prawnej, niż to miało miejsce wcześniej. Wiąże się to z częściowym osłabieniem tradycyjnych cech społecznych (grupowość, harmonia, hierarchia), co skutkuje pewną 
redukcją roli obowiązku wobec grupy i jej członków, skorelowanej z przyjaznym stosunkiem do harmonijnie funkcjonującego otoczenia (szczególnie członków własnej grupy) na rzecz roli kategorii prawa do czegoś, redukcją potrzeby życia $\mathrm{w}$ grupie i oddawania się w opiekę władzy grupowej na rzecz indywidualistycznie określanej swojej pozycji wobec innych. Wpływa to w sposób decydujący na obraz funkcjonowania prawa w tej kulturze, zmieniający sposób traktowania demokracji jako formy organizacji życia społecznego (w kierunku wzmocnienia jej trwałości i otwartości) oraz idei państwa prawnego (w kierunku określania wymogu praworządnego działania organów państwowych). Wzmocnieniu ulega też koncepcja ochrony praw człowieka, zmierzając w kierunku zaakcentowania ich jednostkowego wymiaru oraz wynikających z niego roszczeń obywatela wobec władzy państwowej (i wobec innych jednostek). Następuje również stopniowe wzmacnianie roli prawa pisanego, począwszy od dziedzin podlegających wymianie międzynarodowej, poprzez prawo publiczne (z uregulowaniem w ustawie o procedurze administracyjnej ,nieregulowalnej” dotąd praktyki gyoseishido ${ }^{17}$ ), skończywszy na regulacjach prawa prywatnego, stosunkowo najbardziej zakorzenionych w autonomicznych normach społecznych.

Zasadne jest jednak pytanie o zakres czy trwałość tych zmian i zbliżeń do zachodniej kultury prawnej, oznaczających wszak stopniowe odchodzenie od tradycyjnych wartości i norm społecznych oraz ograniczających postrzeganie tej kultury prawnej jako odformalizowanej, nielegalistycznej i traktującej prawo instrumentalnie. Być może pozostawanie w konwencji utożsamiania prawa ze sferą tatemae jest dziś zbyt daleko idącą generalizacją czy nawet uproszczeniem opisu, ale też teza o pełnej nieaktualności tego związku byłaby z pewnością nietrafna.

Wydaje się, że wyważenie obu racji mogłoby prowadzić do stwierdzenia aktualności dla opisu japońskiego porządku prawnego innego rozróżnienia znanego zachodniej kulturze prawnej. Wymagałoby ono odwołania się do amerykańskiej myśli prawniczej związanej z doktryną funkcjonalizmu prawniczego, co stanowiłoby jednocześnie przykład „nowej recepcji”, tym razem obejmującej tezę teoretycznoprawną (co już zresztą miało miejsce w przypadku recepcji niemieckich rozwiązań prawnych) ${ }^{18}$.

Idzie o rozróżnienie kategorii law in the books oraz kategorii law in the action $^{19}$. Od tezy o prawie jako tatemae kategoria law in the action różni się tym, że wiąże istotę prawa z perspektywą funkcjonalną, jest tezą bardziej miękką, nie wyznacza ostrej i nieprzekraczalnej granicy między sferami, nie pozbawia prawa

17 Por. art. 32-37 ustawy z dnia 12 listopada 1993 r. o procedurze administracyjnej (ustawa nr 88 z 1993 r.).

18 Por. Z. Kitagawa, op. cit., zwłaszcza s. 1-6.

19 Por. O.W. Holmes, The Path of the Law, "Harvard Law Review" 1897, Vol. 10(8), DOI: https://doi.org/10.2307/1322028, s. 457 i n.; R. Pound, The Task of Law, Lancaster 1944, s. 23, 38, 88 i n.; J. Frank, Law and the Modern Mind, London 1949, s. 32-35, 46. 
cechy ,jurydyczności”, lecz wiąże jego istotę ze zjawiskami społecznymi. Oparcie tego rozróżnienia na odrębnej (anglosaskiej) kulturze prawnej i odmiennym (związanym z common law) systemie źródeł prawa (zwłaszcza pozycji precedensów) nie powinno stanowić decydującej przeszkody, ponieważ „szlaki zostały przetarte" przez powojenną recepcję amerykańskich rozwiązań prawnych. Law in the action jest przy tym kategorią na tyle uniwersalną, że nie tylko można ją dostrzec wszędzie tam, gdzie prawo działa, ale też umożliwia ona ustalenie takiej proporcji wykorzystania litery prawa w tym działaniu (niezależnie nawet od tego, czy law in the books to teksty aktów normatywnych czy teksty decyzji sądowych), jaka jest optymalna dla danego porządku społeczno-prawnego. A tak rozumiana „regionalizacja” właściwości uniwersalnych daje się w pełni zaakceptować w japońskim porządku prawnym.

\section{BIBLIOGRAFIA}

Choi C., Ancient and New Sources of Law: An East-Asian Perspective, [w:] Challenge to Law at the End of the $20^{\text {th }}$ Century, ed. E. Pattaro, Vol. 2, Bologna 1995.

Dialogi konfucjańskie, Wrocław 1976.

Doi T., The Anatomy of Self: The Individual versus Society, Tokio-New York 1988.

Dubel L., Malarczyk J., Historia doktryn polityczno-prawnych, Lublin 1997.

Frank J., Law and the Modern Mind, London 1949.

Fujita T., Gyoseishido. Rechtsprobleme eines Hauptmittels der gegenwartigen Verwaltung in Japan, "Die Verwaltung" 1982, Nr. 2.

Haley J.O., The Role of Law in Japan: An Historical Perspective, "Kobe University Law Review" 1984, No. 18.

Hata I., Japan under Occupation, “Japan Interpreter" 1976, No. 3-4.

Hayashi S., Iwayuru Gyosei Shido ni Tsuite, "Gyosei to Keiei” 1962, No. 4.

Historia doktryn politycznych i prawnych do poczatku XX wieku. Materiaty źródtowe, oprac. L. Dubel, Lublin 2003.

Holmes O.W., The Path of the Law, "Harvard Law Review" 1897, Vol. 10(8), DOI: https://doi.org/10.2307/1322028.

Kawashima T., The Legal Consciousness of Contract in Japan, "Law in Japan. An Annual" 1974, No. 7.

Kitagawa Z., Theory Reception - One Aspect of the Development of Japanese Civil Law Science, "Law in Japan. An Annual" 1970, No. 4.

Kość A., Prawo a etyka konfucjańska w historii myśli prawnej Chin, Lublin 1998.

Leszczyński L., Gyoseishido w japońskiej kulturze prawnej. Nieformalne działania administracji a prawo, Lublin 1996.

Leszczyński L., Japonia - kontynuacje i negacje, Lublin 1994.

Mukai K., Toshitani N., Meiji Zenki ni okeru Mimpo-ten hensen no Keika to mondai-ten, "Hosei Shi Kenkyu Bessatsu" 1964, No. 14.

Nakane C., Nihonteki Shakai-Kozo no Hakken, Tokio 1967.

Nakane C., Tatashakai no Ningenkankei - Tanitsushakai no Riron, Tokio 1967.

Narita Y., Administrative Guidance, "Law in Japan. An Annual" 1968, No. 2.

Pound R., The Task of Law, Lancaster 1944.

Seidler G.L., Przedmarksowska myśl polityczna, Kraków 1974. 
Shiono H., Gyosei Shido, “Gyoseiho Koza” 1965, No. 6.

Stępień M., Spór konfucjanistów z legistami. W kręgu chińskiej kultury prawnej, Kraków 2013.

Takayanagi K., Contact of the Common Law with the Civil Law in Japan, "Japan Annual of Law and Politics" 1955, No. 3.

Takayanagi K., The Conceptual Background of the Constitutional Revision Debate in the Constitution Investigation Commission, "The American Journal of Comparative Law" 1967, Vol. 4(1), DOI: https://doi.org/10.2307/837044.

Tanaka J., Shihoken no Genkai, Tokio 1976.

Tuor P., Das Schweizerische Zivilgesetzbuch, Zurich 1934.

Young M.K., The Japanese Legal System, History and Structure, [w:] Doing Business in Japan, ed. Z. Kitagawa, Vol. 2, New York 1986.

\section{SUMMARY}

The Japanese legal system, which is a part of the Far East legal culture, is characterized on the one hand by its susceptibility to reception and adaptation of foreign solutions, and on the other hand by its attachment to domestic legal traditions, closely related to cultural features and social axiology. This causes a certain tension between the letter of law and actually functioning legal norms, visible in the context of the relation between the sources of law and custom and jori, the special role of administrative recommendations (gyoseishido) or the position of mediation in relation to formalized legal procedures. Consequently, this tension, which means opening the law to social norms, can be treated as an element of a specific relation between the spheres of tatemae and honne.

Keywords: Japanese legal order; letter of law; normative openness; social functioning of the law

\section{STRESZCZENIE}

Japoński porządek prawny, będący elementem dalekowschodniej kultury prawnej, charakteryzuje się z jednej strony podatnością na recypowanie i adaptację rozwiązań obcych, natomiast z drugiej - przywiązaniem do rodzimych tradycji prawnych, ściśle powiązanych z cechami kulturowymi i aksjologią społeczną. Powoduje to pewne napięcie między literą prawa a faktycznie funkcjonującymi normami prawnymi, widoczne w kontekście stosunku źródeł prawa stanowionego do zwyczaju i jori, szczególnej roli zaleceń administracyjnych (gyoseishido) czy pozycji mediacji względem sformalizowanych procedur prawnych. W konsekwencji napięcie to, oznaczające otwieranie prawa na normy społeczne, może być potraktowane jako element specyficznej relacji między sferami tatemae i honne.

Słowa kluczowe: japoński porządek prawny; litera prawa; otwartość normatywna; społeczne działanie prawa 